\title{
CASP4 wt Allele
}

National Cancer Institute

\section{Source}

National Cancer Institute. CASP4 wt Allele. NCI Thesaurus. Code C49554.

Human CASP4 wild-type allele is located within 11q22.2-q22.3 and is approximately $27 \mathrm{~kb}$ in length. This allele, which encodes caspase- 4 protein, plays a role in the activation of caspase-1 during apoptosis. 